\title{
Import / Export / \\ Rock'n'Roll - The Movement of Popular Music (Among Other Things) Across the Iron Curtain
}

\section{PetrFerenc}

To the National Museum - Czech Museum of Music, the exhibition Import / Export / Rock'n'Roll brought the theme of popular music of the latter half of the twentieth century, a theme that is especially loaded with socio-political content.

An obvious leitmotif of the exhibition, which was on display in the areas for exhibits from the end of March 2019 to the end of June 2020, is the tension between the spontaneous and the official, the desired and the permitted, the forbidden and the defiant. Before the Velvet Revolution 31 years ago, the presence and "spread of popular music in Czechoslovakia during Normalisation" (the exhibition's subtitle) was a matter over which the state struggled for totalitarian control.

The team of authors limited itself to studying the period of the Berlin Wall's existence, i.e. from 1961 to 1989. Properly speaking, Normalisation did not begin until ca. 1969, but the beginning of the chosen era overlaps more or less with the worldwide advent of "youth culture", of which the most lasting musical product was the brand new and still to this day more or less accepted understanding of the role and importance of popular music and of rock music in particular. In addition, the approach of the Czechoslovak state to Englishlanguage popular music did not change very much with the exception of the thaw before and during the Prague Spring.

To the regime, which had nationalised not only industry, but also culture, it soon became fairly clear that Western popular music (to this day, the words "the Beatles" have lost little of their urgency) could not be ignored, so it committed itself to what now appears to us to be a Quixotic struggle in the field of cultural policy, and it incorporated pop music, beat music, and later rock music into its planning for the generation and approval of "unobjectionable" artistic production. In other words, it assumed the roles of agent, presenter, publisher, manager, and censor.

Unsurprisingly, the result was a shortage. The state was incapable of satisfying the listeners' demand for ideological and economic reasons, but it had no intention of giving 

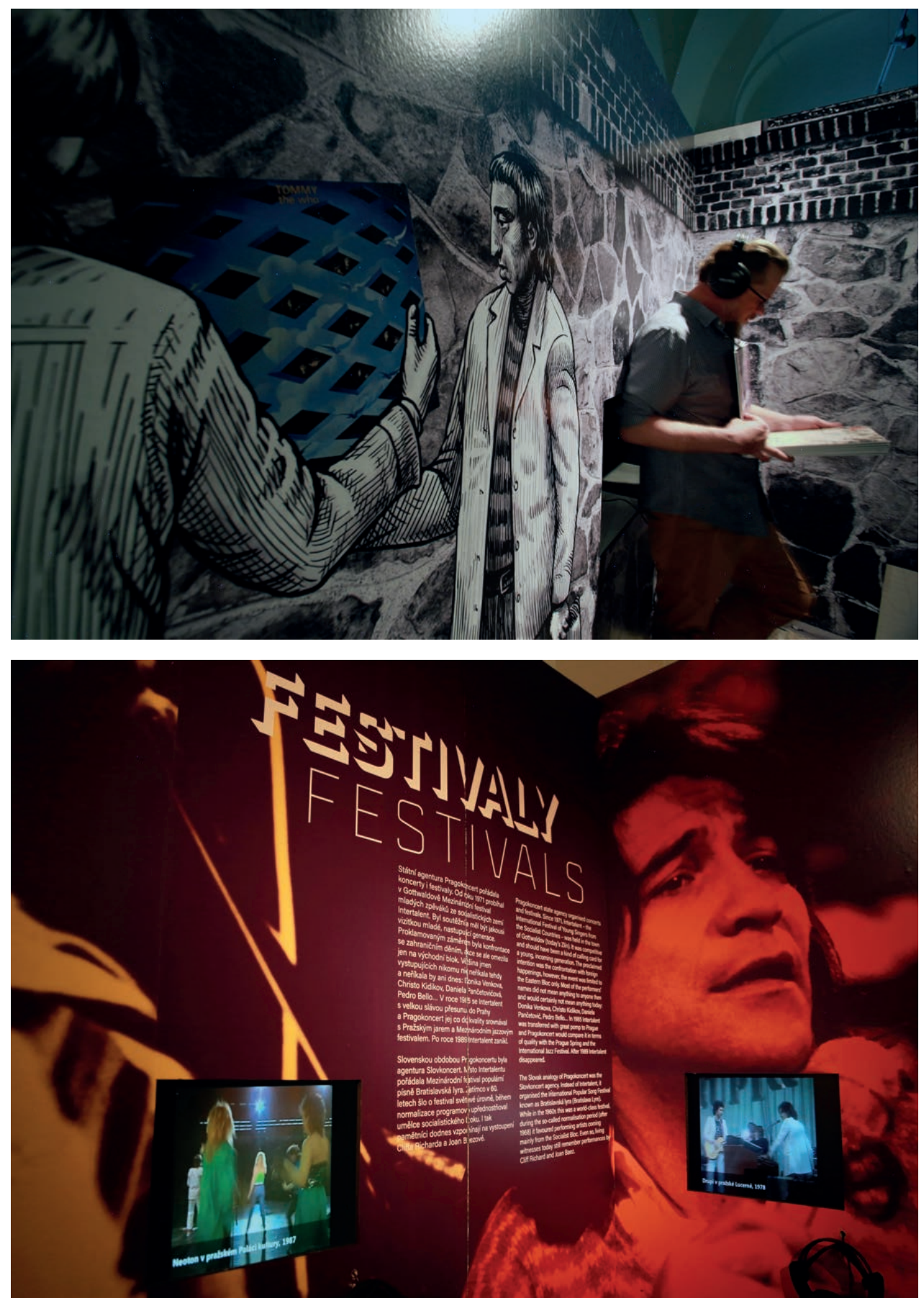

A look at the exhibition Import / Export / Rock'n'Roll Pohledy do výstavy Import / Export / Rock'n'Roll

(c) NM 
up its monopoly. It retained control over foreign trade, and it prosecuted any kind of spontaneous, do-it-yourself activities as disorderly conduct or trafficking in illegal goods. Broken down into several topical categories (radio, "magnitizdat", i.e. unauthorised selfpublishing of recordings, licensed recordings, black markets, concerts, Tuzex, ${ }^{1}$ exile), the exhibition Import / Export / Rock'n'Roll offered insights into the degree to which the state succeeded.

In view of the fact that pop music truly was a mass phenomenon, and was not just proclaimed as such, most of the exhibits on display consisted of various kinds of "multiples", i.e. gramophone record covers, packaging for cassette tapes, and a wide variety of musical printed matter. Audiovisual content in the form of period video clips, recorded live concerts, and excerpts from songs was supplemented by material such as film works by Petr Nikolaev, Jan Ságl, and Milan Kníżák that are not routinely shown. Interactive aspects of the exhibition included the opportunity to play creatively with gramophones, tape recorders, and an analogue synthesiser, and there was also a popular exhibit of licensed gramophone records published by Supraphon and Opus, which were presented in the form of a record shop.

Individual rooms of the exhibition were dedicated to the reception and jamming of Western radio stations like Radio Free Europe or Radio Luxembourg (RTL), the more-orless tolerated musical press (the journal Melodie vs. the publications of the Jazz Section), the infrequent stops made in Czechoslovakia by foreign stars on world tours, and foreign repertoire with the original texts replaced by words in Czech. Sometimes truly bizarre controversies were among the few ways to get foreign repertoire played on radio and television. One of the attractions of the exhibition was a screen with the original side-byside with a cover version with original clips. The viewer could use a switch to choose which soundtrack to listen to.

Thanks to the layout of the Czech Museum of Music, the original cobblestone floor of a small part of the building helped create the illusion of the Prague street Španělská as one of the sites of the frequently relocated Sunday black market for gramophone records. One interesting interactive exhibit consisted of mock-ups of titles that are documented by period photographs or film footage as having been sold at the markets; holding the cover up to a sensor activated playback of the song in question in headphones.

The exhibition also devoted space to non-English-speaking foreign popular music. Besides Italian pop (and the exceptional case of the American singer and actor Dean Reed, who decided to "immigrate to the East"), this mostly involved music of from the allied countries of the Eastern Bloc, the distribution of which was strongly supported through festivals like Intertalent or Bratislava Lyre.

The efforts to export Czechoslovak popular music beyond the country's borders were represented by Václav Neckářs licensed albums and the covers of the groups Olympic and Blue Effect sung in the languages of the target market, i.e. German or English. A particular

1) Tuzex was a store chain that sold luxury items and did not accept payment in Czechoslovak currency. Customers paid using vouchers received from banks (or the black market) in exchange for hard currency from abroad. Tuzex went out of business in 1992. 
type of export was presented in the final room devoted to exiled musicians and producers (Karel Kryl, the Šafrán 78 label, Jan Hammer Jr., Jiří Smetana, Ivan Kral...).

One of the most attractive exhibits was a Czechoslovak Grazioso electric guitar, which won a prize at Expo 58 in Brussels. It was exported to the United Kingdom under the trademark Futurama, and George Harrison and Jimmy Page were among the players who used it as novice musicians. Commemorating the samizdat era are pressings of sound recordings made on x-ray film, reel-to-reel tape recorders, and the so-called "police book" of the samizdat publisher Petr Cibulka.

The visitors to the exhibition who had lived through the period in question best understood the ambiguity of experiencing the still living history of everyday life - in their thoughts, memories of repression involving access to current popular music from the West were intermingled with nostalgic recollections associated with the music heard in spite of the authorities. The authors and instructors used worksheets and guided tours to try to elicit the same feelings among the younger or foreign visitors.

Besides guided tours (Petr Ferenc, Mariana Lebedová) and school field trips with instructors, there were a number of auxiliary programmes at the exhibition, such as concerts given by Mikoláš Chadima and his group Extempore, and Milan Knížák, whose "broken music" was presented at the exhibition as a subgenre of avant-garde music that emerged in Czechoslovakia and first gained recognition beyond the country's borders.

Those who remember the gramophone markets were able to reminisce about them twice in the museum hall, and the café was used more than once for listening programmes and forums. Besides the dean of Czech musical journalism Jiři Černý, guests were recruited mostly from among members and fans of the Jazz Section. Cooperation between the Czech Museum of Music and the successor organisation Jazz Section 1971-1988 led in 2019 to the creation of the Jazz Section Centre, which plans to acquire and research the archival material of the original Jazz Section. The exhibition Import / Export / Rock'n'Roll can be said to be resonating at the National Museum even now that it is over.

\section{Team of Authors}

Authors of the exhibition: Peter Balog, Petr Ferenc, Mariana Lebedová, Kamila Marešová Exhibition curators: Mariana Lebedová, Kamila Marešová

Production: Tereza Lišková, Martin Musil

Architectural and interior design: Lucie Kirovová, Ondřej Teplý

Graphics: Ondřej Zámiš

Address: Petr Ferenc, České muzeum hudby, Karmelitská 2, Praha 1, Czech Republic E-mail:petr.ferenc@nm.cz 


\section{Import / Export / Rock'n'Roll - Nejen o pohybu populární hudby pres železnou oponu}

\section{PetrFerenc}

Výstavou Import / Export / Rock'n'Roll vstoupilo do Národního muzea - Českého muzea hudby téma populární hudby druhé poloviny 20 . století, tedy téma nabité především společenskopolitickým obsahem.

Evidentním leitmotivem přehlídky, jež byla ve výstavních prostorách umístěna od konce března 2019 do konce června 2020, je napětí mezi spontánním a oficiálním, touženým a povoleným, zapovězeným a vyvzdorovaným. Provozování a „šírení populární hudby v normalizačním Československu" (jak zněl podtitul výstavy) bylo až do listopadového převratu před jednatřiceti lety záležitostí boje o totální státní kontrolu.

Autorský tým vymezil zkoumané období existencí Berlínské zdi, tedy lety 1961-1989. O normalizaci sice můžeme hovořit až přibližně od roku 1969, počátek zvolené éry se ale víceméně kryje s celosvětovým nástupem "mládežnické“ kultury, jejímž nejtrvalejším hudebním plodem bude zcela nové, dodnes víceméně platné chápání role a významu populární, především rockové hudby. Přístup československého státu k anglofonní populární hudbě se navíc s výjimkou uvolnění před Pražským jarem a v jeho průběhu zas tolik neměnil.

Režimu, který znárodnil a centralizoval nejen výrobu, ale i kulturu, začalo být poměrně brzy zřejmé, že západní populární hudbu (klíčové slovo Beatles dodnes ztratilo jen málo ze své naléhavosti) nelze ignorovat. Pustil se tedy do dnešníma očima donkichotského boje na poli kulturní politiky a zařadil pop music, beat, později rock do svého plánování výroby i schvalování „nezávadné“ umělecké produkce. Jinými slovy, vzal na sebe roli agentury, pořadatele, nakladatele, manažera i cenzora.

Nepřekvapivým důsledkem byl nedostatek. Poptávku posluchačů stát nebyl s to uspokojit z ideologických i ekonomických důvodů, monopolu se ale nehodlal vzdát, stál o zahraniční obchod a jakoukoli spontánní (do-it-yourself) aktivitu stíhal jako výtržnictví či nedovolené podnikání. Výstava Import / Export / Rock'n'Roll přinesla v několika tematických okruzích rozhlas, magnitizdat, licencované nahrávky, černé burzy, koncerty, tuzex, exil - pohledy na to, do jaké míry se mu to dařilo. 


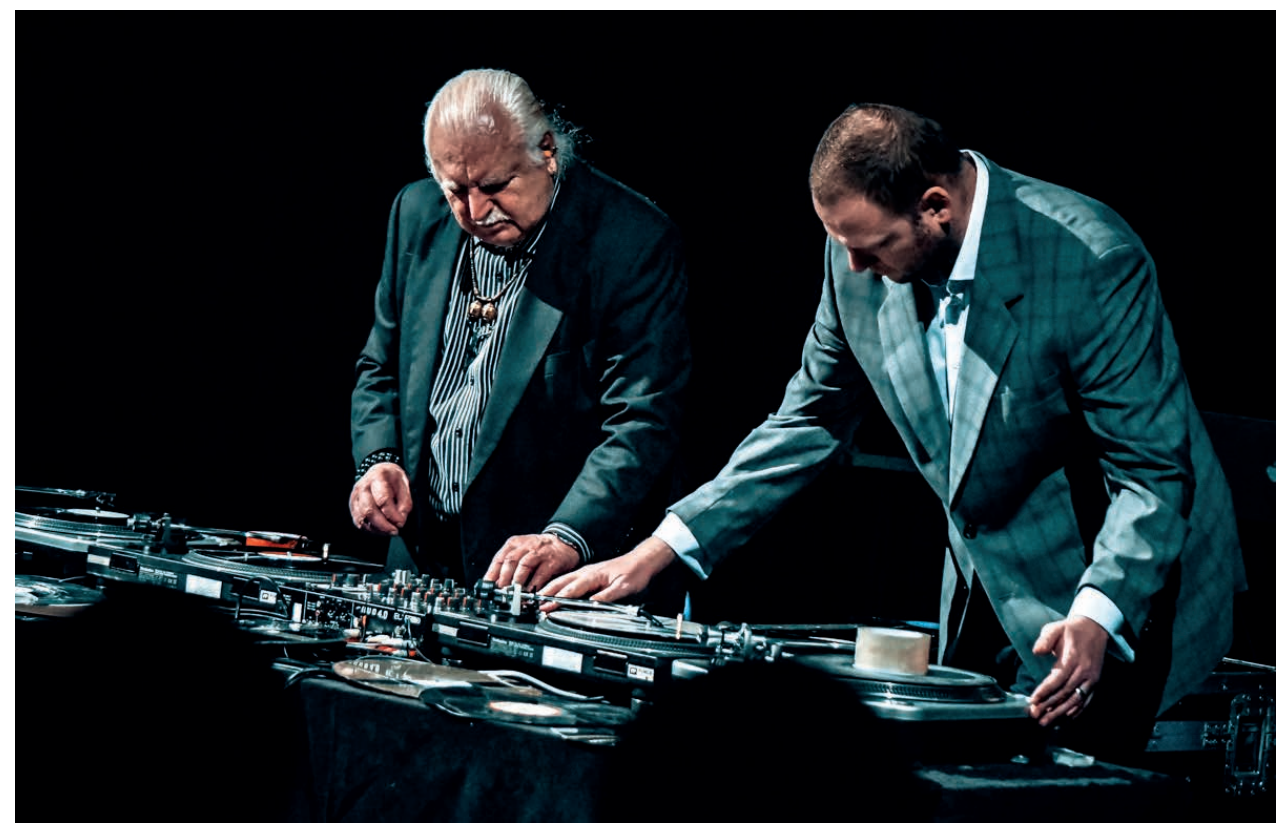

Milan Knížák and Petr Ferenc in a programme of deconstructed music titled BROKEN REBROKEN / Milan Knížák a Petr Ferenc v programu destruované hudby BROKEN REBROKEN (c) Anna Baštýřová

Vzhledem ke skutečné, nikoliv pouze proklamované masovosti pop music tvořily většinu vystavených exponátů nejrůznější typy multiples, přesněji obaly gramofonových desek a magnetofonových kazet a nejrůznější hudební tiskoviny. Audiovizuální obsah v podobě dobových videoklipů, koncertních záznamů a písňových ukázek byl doplněn mj. běžně neuváděnými filmovými díly Petra Nikolaeva, Jana Ságla a Milana Knížáka. Interaktivní stránku výstavy doplňovaly možnosti tvůrčí hry s gramofony, magnetofony a analogovým syntetizérem, popularitě se těšila i expozice licenčních desek vydavatelství Supraphon a Opus prezentovaná formou prodejny s gramodeskami.

Jednotlivé místnosti výstavy byly věnovány př́imu a rušení západních rozhlasových stanic typu Svobodné Evropy či Radia Luxembourg, více i méně povolovanému hudebnímu tisku (časopis Melodie versus publikace Jazzové sekce), nečetným československým zastávkám na turné zahraničních hvězd i zahraničnímu repertoáru přetextovanému do češtiny. Místy opravdu bizarní coververze byly jednou z nemnoha možností, jak dostat zahraniční repertoár do rozhlasu i televize. Obrazovka, na níž vedle sebe běží originál a coververze is původními klipy a divák může přepínačem volit zvukovou stopu, byla jednou z atrakcí výstavy.

Díky dispozici Českého muzea hudby mohla na původních kočičích hlavách, jež se nalézají v malé části objektu, vyrůst iluze pražské Španělské ulice coby jednoho z dějišt́ často se stěhujících nedělních černých burz s gramodeskami. Zajímavým interaktivním prvkem byly makety titulů, jež se na burzách dle dobových fotografií i filmových záznamů prokazatelně prodávaly; po přiložení obalu k čidlu zazněla ve sluchátkách patřičná píseň. 
Své místo měla na výstavě i neanglofonní zahraniční populární hudba. Kromě italské (a výjimky v osobě amerického zpěváka a herce Deana Reeda, jenž se rozhodl „emigrovat na východ“) šlo vesměs o hudbu spřátelených států východního bloku, jejíž šíření stát výrazně podporoval velkorysými festivaly typu Intertalent či Bratislavská lyra.

Snahy o export československé populární hudby za hranice státu byly přiblíženy licenčními alby Václava Neckáře a skupin Olympic a Blue Effect přezpívanými do jazyků cílového trhu, tedy do němčiny, resp. angličtiny. Určitý druh vývozu představila i závěrečná místnost věnovaná exulantům z řad hudebníků i vydavatelů (Karel Kryl, Šafrán, Jan Hammer ml., Jiří Smetana, Ivan Kral...).

$\mathrm{K}$ nejatraktivnějším exponátům patřila československá elektrická kytara Grazioso, jež získala ocenění na bruselské výstavě Expo 58, pod jménem Futurama se vyvážela do Británie a coby začínající hudebníci na ni hráli mj. George Harrison a Jimmy Page. Éru samizdatu prripomněla ryčka zvukových záznamů do rentgenových
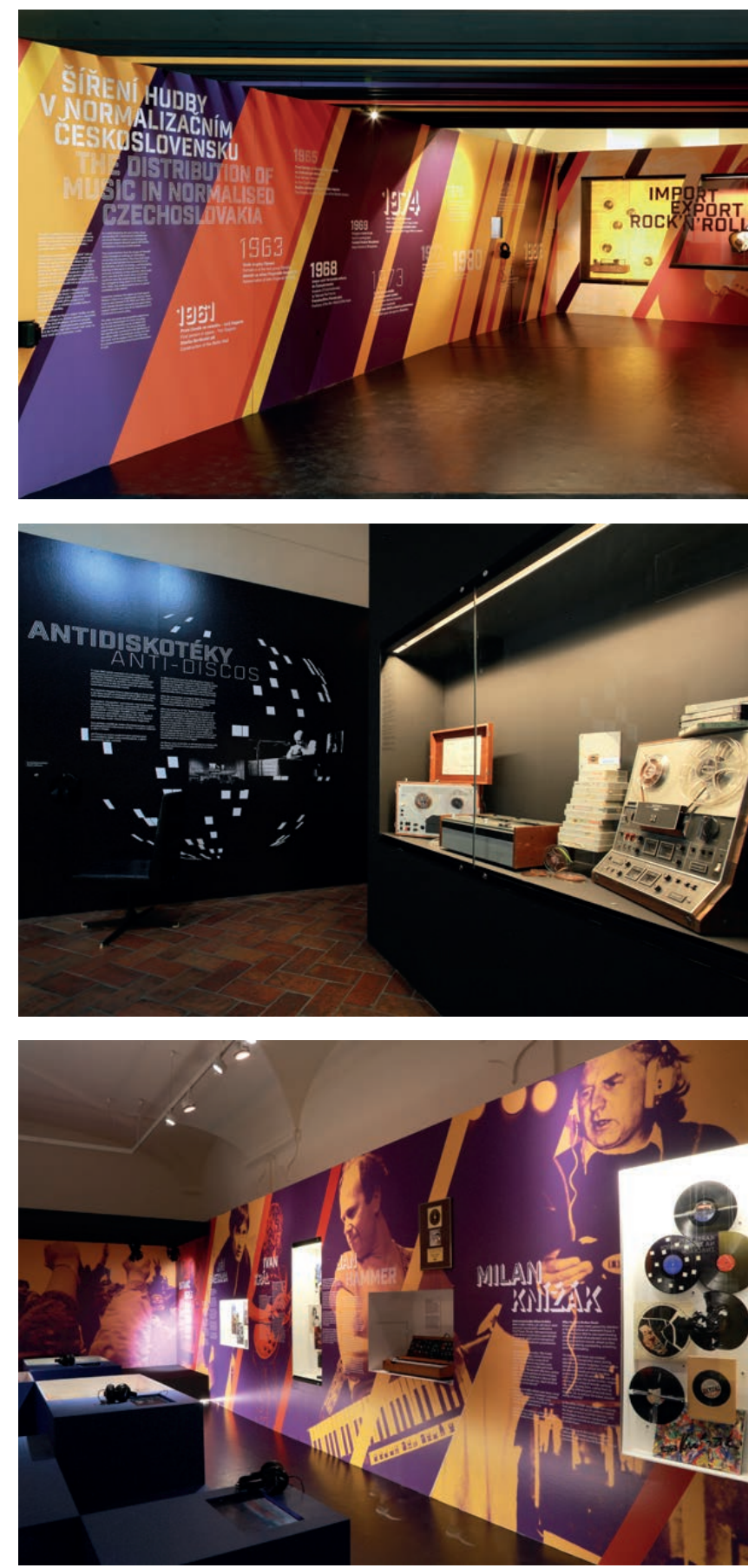

A look at the exhibition Import / Export / Rock'n'Roll Pohledy do výstavy Import / Export / Rock'n'Roll (๑) NM 


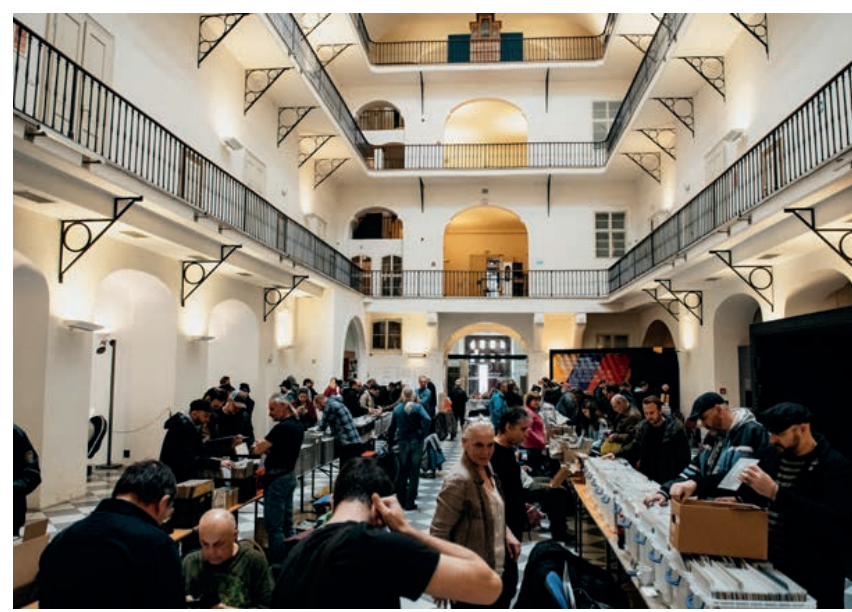

Markets with gramophone records held twice in the hall of the Czech Museum of Music / Burzy s gramodeskami proběhly dvakrát ve dvoraně Českého muzea hudby (c) NM fólií, cívkové magnetofony i tzv. „policejní kniha“ samizdatového vydavatele Petra Cibulky.

Návštěvníci výstavy z řad pamětníků nejlépe chápali dvojznačnost zakoušení ještě živých dějin každodennosti - vzpomínky na represe týkající se př́stupu k aktuální západní populární hudbě se v nich mísily s nostalgickými vzpomínkami spojenými s hudbou slyšenou těmto represím navzdory. Stejné pocity se autoři a lektoři snažili for-

mou pracovních listů a komentovaných prohlídek vyvolat i v mladších či zahraničních návštěvnících.

Kromě komentovaných prohlídek (Petr Ferenc, Mariana Lebedová) a lektorovaných exkurzí pro školy v rámci výstavy proběhla řada doprovodných programů, například koncerty Mikoláše Chadimy a skupiny Extempore či Milana Knížáka, jehož destruovaná hudba byla ve výstavě zastoupena coby subžánr avantgardní hudby, jenž se zrodil v Československu a uznání došel nejprve za hranicemi.

Pamětníci burz s gramodeskami si tyto burzy dvakrát mohli připomenout ve dvoraně muzea, kavárna nejednou patřila poslechovým pořadům a besedám. Kromě nestora české hudební publicistiky Jiř́ho Černého se hosté rekrutovali většinou z řad členů a příznivců Jazzové sekce. Spolupráce Českého muzea hudby s nástupnickou Jazzovou sekcí 1971-1988 dala v roce 2019 vzniknout Centru jazzové sekce, jež má v plánu akvizice a výzkum archiválií původní Jazzové sekce. Dá se tedy říci, že výstava Import / Export / Rock'n’Roll rezonuje Národním muzeem i po svém zakončení.

\section{Autorský tým}

Autoři výstavy: Peter Balog, Petr Ferenc, Mariana Lebedová, Kamila Marešová

Kurátorky výstavy: Mariana Lebedová, Kamila Marešová

Produkce: Tereza Lišková, Martin Musil

Architektonické a interiérové řešení: Lucie Kirovová, Ondřej Teplý

Grafika: Ondřej Zámiš

Adresa: Petr Ferenc, České muzeum hudby, Karmelitská 2, 11800 Praha 1, Česká republika E-mail: petr.ferenc@nm.cz 